\title{
Clinical Outcomes of TP53 Mutations in Cancers
}

\author{
Ana I. Robles, ${ }^{1}$ Jin Jen, ${ }^{2}$ and Curtis C. Harris ${ }^{1}$ \\ ${ }^{1}$ Laboratory of Human Carcinogenesis, Center for Cancer Research, National Cancer Institute, National \\ Institutes of Health, Bethesda, Maryland 20892 \\ ${ }^{2}$ Department of Laboratory Medicine and Pathology, Division of Experimental Pathology, and Department \\ of Medicine, Division of Pulmonary and Critical Care Medicine, Mayo Clinic, Rochester, Minnesota 55905 \\ Correspondence: curtis_harris@nih.gov
}

\begin{abstract}
High-throughput sequencing of cancer genomes is increasingly becoming an essential tool of clinical oncology that facilitates target identification and targeted therapy within the context of precision medicine. The cumulative profiles of somatic mutations in cancer yielded by comprehensive molecular studies also constitute a fingerprint of historical exposures to exogenous and endogenous mutagens, providing insight into cancer evolution and etiology. Mutational signatures that were first established by inspection of the TP53 gene somatic landscape have now been confirmed and expanded by comprehensive sequencing studies. Further, the degree of granularity achieved by deep sequencing allows detection of low-abundance mutations with clinical relevance. In tumors, they represent the emergence of small aggressive clones; in normal tissues, they signal a mutagenic exposure related to cancer risk; and, in blood, they may soon become effective surveillance tools for diagnostic purposes and for monitoring of cancer prognosis and recurrence.
\end{abstract}

In the 5 years since our earlier review (Robles and Harris 2010), next-generation sequencing (NGS) has become the new standard for mutation testing that is rapidly being adopted in the clinic. In addition, the comprehensive characterization of human cancer genomes led by The Cancer Genome Atlas (TCGA) project (cancergenome.nih.gov) and the International Cancer Genome Consortium (ICGC) project (icgc.org) has ushered in the era of clinical genomics, in which molecular features are becoming an essential tool for cancer taxonomy. These studies have provided an unprecedented amount of information on TP53 mutations and their association to important exposure and clinical variables. Herein, we provide an update on the state of TP53 mutation testing in the context of clinical genomics and explore recent advances in the field and emerging areas of application.

\section{METHODOLOGIES USED IN ASSESSMENT OF p53 STATUS IN CLINICAL AND EPIDEMIOLOGICAL STUDIES}

Sanger sequencing relies on the chain-termination method, which uses labeled termination nucleotides (ddNTPs) during DNA synthesis by DNA polymerase to generate DNA fragments varying by one base from each other and then separated by electrophoresis (Sanger et al. 1977). Variations and improvements on

Editors: Guillermina Lozano and Arnold J. Levine

Additional Perspectives on The p53 Protein available at www.perspectivesinmedicine.org

Copyright (C) 2016 Cold Spring Harbor Laboratory Press; all rights reserved; doi: 10.1101/cshperspect.a026294

Cite this article as Cold Spring Harb Perspect Med 2015;6:a026294 
A.I. Robles et al.

this technique were the gold standard for sequencing for $>30$ years after its development. Although much less used, Sanger sequencing still remains one of the most reliable, fail-proof, and simple methods to assess the nucleotide sequence in a given DNA sample. Even today, it is not uncommon for molecular alterations observed by NGS to be validated using Sanger sequencing (Jelinic et al. 2014; Streppel et al. 2014).

In the past decade, the cost and turnaround time (TAT) of NGS have decreased significantly, and the technology has matured to make it practical to use NGS platforms for gene mutation testing in routine clinical settings. NGSbased platforms use a massively parallel strategy capable of concurrently interrogating hundreds of thousands to millions nucleotide sequences of a given sample at the resolution of single molecules. The generated sequences are mapped to the reference genome and computationally summarized to reveal the quality of the read, type of the nucleotide, and the number of read evidence at each base position. Genomic status of TP53 can be identified as part of whole-genome or whole-exome sequencing efforts such as those performed by TCGA (Kandoth et al. 2013). It can also be done through targeted approaches that involve either multiplex polymerase chain reaction (PCR)-based gene panels or hybrid capture of targeted genes followed by NGS sequencing, such as Life Technologies' AmpliSeq (Tsongalis et al. 2014), Foundation Medicine (Frampton et al. 2013), Personal Genome Diagnostics (PGDx, Baltimore, MD), and others. In clinical settings,
NGS-based TP53 sequence analysis is usually done using targeted approaches because of the relatively lower cost and faster TAT for data generation and analysis. A comparison of these approaches is summarized in Table 1.

\section{GERMLINE TP53 MUTATIONS AND CANCER PREDISPOSITION}

The cancer predisposition syndrome that would come to be known as $\mathrm{Li}$-Fraumeni syndrome (LFS; OMIM \#151623, omim.org) was initially identified among families with a high incidence of childhood cancers, particularly sarcomas, early-onset cancers, and multiple primary tumors (Li and Fraumeni 1969; see also the review by Guha and Malkin 2016). An epidemiological link between germline TP53 mutations and LFS was made shortly after the discovery of p 53 , as it was realized that sporadic forms of the same types of cancers observed in patients with clinical features of LFS carried somatic inactivation of TP53 (Malkin et al. 1990; Srivastava et al. 1990). Diagnostic testing for germline TP53 mutations is based on criteria that take into account the presence of early-onset tumors within the LFS tumor spectrum as well as familial aggregation and multiplicity of cancers ( $\mathrm{Li}$ et al. 1988; Kamihara et al. 2014). Recently, testing recommendations have been broadened to include women with early-onset breast cancer in the absence of family history or BRCA1/ BRCA2 mutations (McCuaig et al. 2012), as they would be suspected of carrying de novo TP53 germline mutations (Gonzalez et al. 2009). In addition, germline TP53 mutations

Table 1. Comparison of methods used to sequence TP53

\begin{tabular}{|c|c|c|c|c|c|}
\hline $\begin{array}{l}\text { Sequencing } \\
\text { technology }\end{array}$ & Platform & Sample requirement & $\begin{array}{c}\text { Data } \\
\text { analysis }\end{array}$ & $\begin{array}{l}\text { Turnaround } \\
\text { time }\end{array}$ & $\begin{array}{c}\text { In clinical } \\
\text { use }\end{array}$ \\
\hline Sanger & ABi 7300 & FFPE, FF $10-100$ ng & Easy & $1-2$ days & Yes \\
\hline $\begin{array}{l}\text { Targeted gene } \\
\text { panels }^{\mathrm{a}}\end{array}$ & $\begin{array}{l}\text { Illumina MiSeq, Ion } \\
\text { Torrent, PacBio RS }\end{array}$ & $\begin{array}{l}\text { FFPE compatible } \\
\quad 10-500 \text { ng }\end{array}$ & Moderate & $1-2$ weeks & Yes \\
\hline $\begin{array}{l}\text { Whole genome/ } \\
\text { exome }\end{array}$ & $\begin{array}{l}\text { Illumina HiSeq } 2000 \text { or } \\
\text { higher }\end{array}$ & $\begin{array}{l}\mathrm{FF} \text { (mostly), FFPE } \\
0.5-1 \mu \mathrm{g}\end{array}$ & Complex & $\geq 4-6$ weeks & No \\
\hline
\end{tabular}

${ }^{\mathrm{a} E x a m p l e s ~ o f ~ t a r g e t e d ~ g e n e ~ p a n e l s ~ a r e ~ t h o s e ~ p r o v i d e d ~ b y ~ F o u n d a t i o n ~ M e d i c i n e, ~ P e r s o n a l ~ G e n o m e ~ D i a g n o s t i c s, ~ a n d ~ L i f e ~}$ Technologies' AmpliSeq.

FFPE, Formalin-fixed paraffin-embedded; FF, fresh-frozen. 
have now been uncovered in patients who did not fulfill the clinical criteria for LFS testing, but presented with rare pediatric cancers including hypodiploid acute lymphoblastic leukemia (Holmfeldt et al. 2013), melanoma (Lu et al. 2015), gastric adenocarcinoma (Chang et al. 2013), early-onset colorectal cancer (Yurgelun et al. 2015), early-onset osteosarcoma (Mirabello et al. 2015), or multiple early-onset malignancies (Yamada et al. 2009; Chak et al. 2015). The wide application of NGS technologies will undoubtedly lead to more such findings and require continued reassessment of the role of TP53 germline variants in cancer predisposition and the need for intense surveillance of mutation carriers and their families (Villani et al. 2011).

\section{THE TP53 MUTATION LANDSCAPE AS A FOOTPRINT OF THE EXPOSOME}

The patterns and spectra of TP53 mutations have long been recognized as molecular links to the exposome, a term coined by Christopher Wild to globally refer to environmental exposures (e.g., smoking and diet) and internal consequences (e.g., obesity and inflammation) during an individual's lifetime (Wild 2005). Genotoxic exposures to environmental carcinogens and endogenous mutagens promote specific sequence base changes that provide clues to the etiological origins of cancer (Hollstein et al. 1991; Hussain and Harris 1999; Olivier et al. 2010; Schetter and Harris 2012). TP53 somatic mutations and the exposome were first linked with the discovery that dietary exposure to aflatoxin B1, a chemical carcinogen found in crops contaminated with the mold Aspergilla flavus, caused a specific G:C > T:A transversion at codon 249 of TP53, R249S, in hepatocellular carcinoma from geographical areas with endemic hepatitis B virus infection (Bressac et al. 1991; Hsu et al. 1991). Exposure to ultraviolet light from the sun was found to cause characteristic CC $>$ TT tandem transitions in TP53 in nonmelanoma skin cancers (Brash et al. 1991). Similarly, cigarette smoke is molecularly linked to G:C > T:A transversions in TP53 in lung cancers (Suzuki et al. 1992). Recently, exposure to aristolochic acid was found to cause A:T $>$ T:A transversions in TP53 in urothelial carcinomas (Moriya et al. 2011; Chen et al. 2012). Signatures of these mutational processes that were first described by their characteristic footprint on TP53 have now been confirmed and generalized by recent comprehensive sequencing studies of cancer genomes (Alexandrov et al. 2013; Lawrence et al. 2013; Poon et al. 2013; Schulze et al. 2015). Importantly, accumulation of somatic TP53 mutations in histologically normal tissues can be readout for exposure to agents etiologically linked to cancer and serve as an early biomarker for risk (Hussain et al. 2000a,b, 2001). Examples of the powerful application of NGS are the identification of patients at high risk for developing cancer by the presence of low-abundance somatic TP53 mutations in gastric mucosal tissues with Helicobacter pylori-induced gastritis (Shimizu et al. 2014), or in Barrett's esophagus tissues (Weaver et al. 2014).

\section{CLINICAL IMPLICATIONS OF SOMATIC TP53 MUTATION}

Chromosomal losses involving chromosome 17 p, where TP53 resides, occur less frequently than deletions of other tumor-suppressor genes (Fig. 1) (Weinberg 1991). Instead, somatic alteration of TP53 is most commonly characterized by recurrent nonsynonymous missense or nonsense mutations and small deletions along the entire gene (Fig. 2). For more than two decades, it has been known that somatic mutations in TP53 occur frequently in human cancers arising from diverse tissue types (Nigro et al. 1989; Hollstein et al. 1991). NGS sequencing of cancer genomes revealed the rate of somatic TP53 mutation to be even higher than previously thought, depending on tissue of origin (Kandoth et al. 2013). TP53 is the most frequently mutated gene across 3281 tumors from 12 cancer types analyzed by unbiased high-throughput sequencing, showing sequence alterations in $42 \%$ of tumors (Kandoth et al. 2013). Overall, the frequency of TP53 alterations varies widely, depending on tissue of origin and histological subtype (Fig. 3). Large- 
A.I. Robles et al.

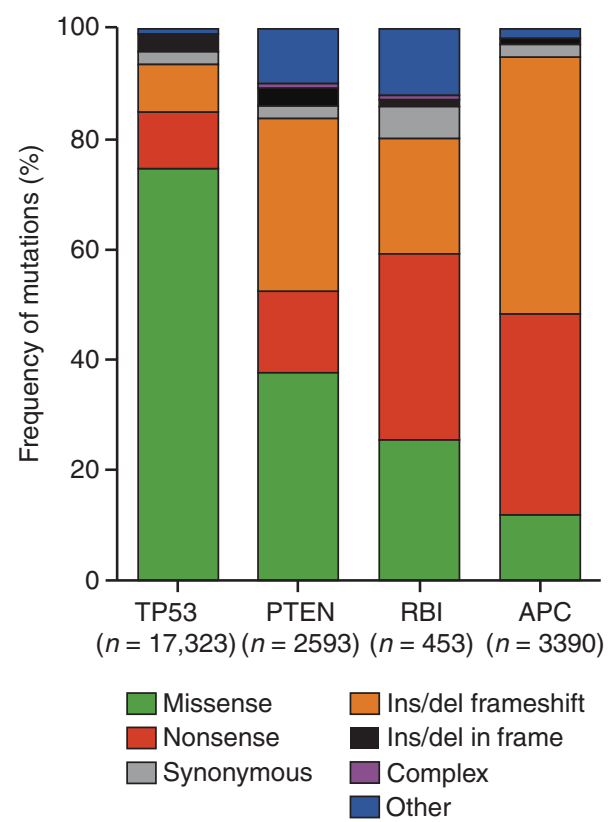

Figure 1. Frequency of mutation types found in the tumor-suppressor genes TP53, PTEN, RB1, and APC. Mutations are classified as substitution, deletion, insertion, or complex mutations. The "other" category contains all those mutations that fall outside the defined categories or for which there is no information on nucleotide changes. Color codes are indicated. Data was downloaded from COSMIC (cancer.san ger.ac.uk) (Forbes et al. 2015) and includes only tumor samples.

scale sequencing efforts have also brought renewed interest in the prognostic value of TP53 mutations in the context of clinical genomics. These studies have confirmed the association of TP53 mutations with more aggressive tumors and poor overall outcome in various cancer types (Cleary et al. 2013; Kandoth et al. 2013; Churi et al. 2014; Tirode et al. 2014; Moreira et al. 2015; Parry et al. 2015). The clinical value of TP53 mutation is strongest in hematological malignancies. In these cancers, TP53 mutations, although relatively infrequent overall $(5 \%-$ $15 \%)$, are correlated with abnormal karyotypes (including loss of $17 \mathrm{p}$ ) and clearly associated with poor outcome (Zenz et al. 2010; Rucker et al. 2012; Kulasekararaj et al. 2013; Malcikova et al. 2014; Stengel et al. 2014; Parkin et al. 2015).

\section{FUNCTIONAL CLASSIFICATION OF TP53 MUTATIONS AND THEIR CLINICAL IMPACT}

p53 is a transcription factor activated by cellular stress that regulates gene expression via sequence-specific recognition of a responsive element consisting of variations of a consensus comprised of two decamers (PuPuPuC(A/ $\mathrm{T})(\mathrm{T} / \mathrm{A}) \mathrm{GPyPyPy}$ ) separated by a variablelength spacer (el-Deiry et al. 1992). Missense substitutions affect p53's transcriptional activity to various degrees, depending on the specific location of the substitution, the amino-acid change, and the cellular context (Kato et al. 2003). These mutations can be broadly categorized on the basis of the type of molecular disruption and the biological consequences on the wild-type (WT) p53 protein. TP53 mutations may lead to complete loss of tumor-suppressor properties (loss of function), enable mutated p53 to form a heterodimer with the remaining WT protein and block its activity (dominantnegative), or confer a conformational change on the protein that allows it to interact differently with its downstream effector proteins or bind entirely new DNA target sequences gain of function (GOF) (Oren and Rotter 2010; Bisio et al. 2014). A more detailed picture of the impact of TP53 somatic mutations on the outcome of cancer patients has started to emerge through the systematic classification of missense TP53 mutations based on DNA binding and transcriptional and oncogenic properties of mutant p53. In breast cancer, for example, it is well established that missense mutations affecting DNA binding are associated with worse patient survival than missense mutations outside of DNA-binding motifs (Olivier et al. 2006). It has since become apparent that the specific functional properties of p53 mutant proteins play a key role in conferring several tumor types with poor prognosis and therapeutic resistance (Poeta et al. 2007; Govindan and Weber 2014; Molina-Vila et al. 2014; Brachova et al. 2015). Crystallographic studies focused on the interaction of p53 and its cancer-associated mutants with DNA have led to a classification system that defines mutations occurring in the p53DNA-binding surface as contact mutations 


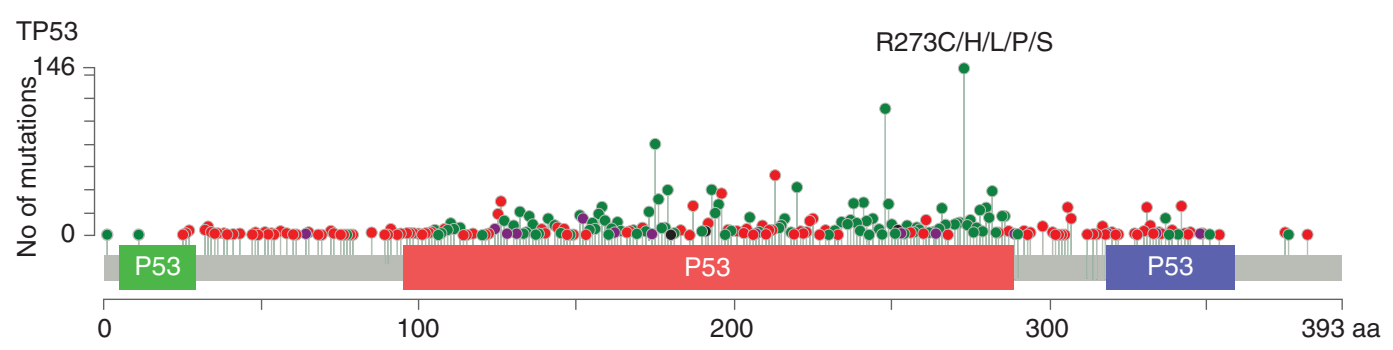

Figure 2. Distribution of TP53 mutations in cancer genomes analyzed by exome sequencing. Figure was generated by the cBio Cancer Genomics Portal (cbioportal.org) (Cerami et al. 2012). Mutation diagram circles are colored with respect to the most frequent mutation type at that position (green, missense; red, truncating; black, in-frame deletion (del)/insertion (ins); gray, splice-site; purple, different mutation types at the same proportion). P53_TAD, P53 transactivation motif (5-29); P53, P53 DNA-binding domain (95-289); P53_tetramer, P53 tetramerization motif (318-359).

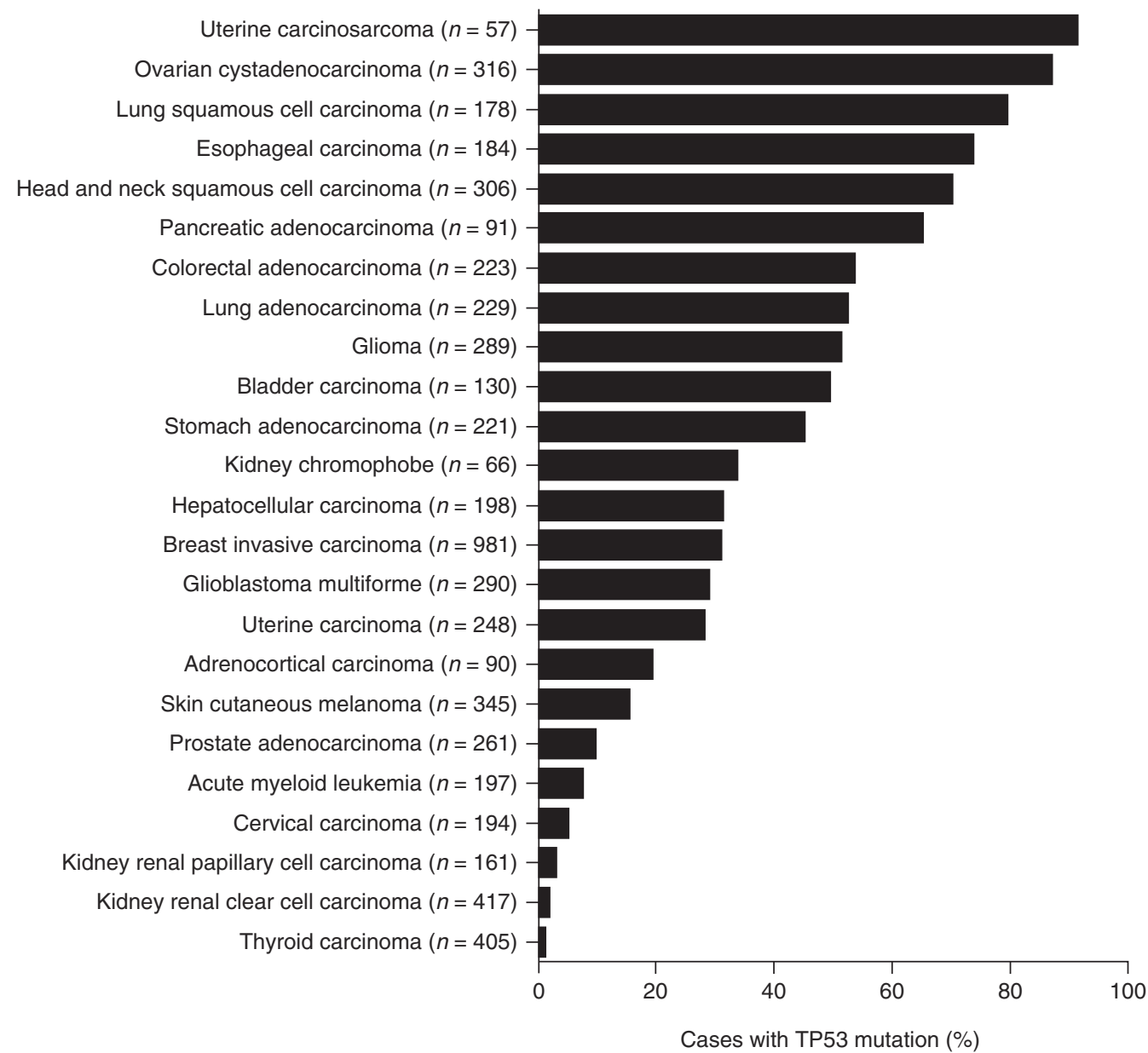

Figure 3. Frequency of TP53 mutations in 24 cancer genomes analyzed by The Cancer Genome Atlas (TCGA) using exome sequencing. The cBio Cancer Genomics Portal (cbioportal.org) (Cerami et al. 2012) was used to interrogate TP53 mutation frequency in each tumor data set, except for esophageal carcinoma data, which was downloaded from TCGA Data Portal (tcga-data.nci.nih.gov). 
A.I. Robles et al.

(e.g., those involving residues R273 and R248) and those that cause conformational instability of the p53 protein as structural mutations (e.g., those involving residues R175, G245, R249, and R282) (Joerger et al. 2006). It has recently been proposed that missense mutations resulting in oncogenic properties that are independent of WT p53 (such as those occurring at codons R248, R273, and R175) should be named "oncomorphic" mutations, to emphasize the fact that they lead to loss of WT function concomitant with gain of oncogenic function (Brachova et al. 2013). In patients diagnosed with advanced serous ovarian carcinoma oncomorphic, TP53 mutations predict resistance to chemotherapy (Brachova et al. 2015). Another mutation classification system is based on the degree of perturbation they impose on p53's transcriptional activity. Mutations are considered "disruptive" if they lead to complete or near complete loss of transcriptional activity, and "nondisruptive" if they do not (Poeta et al. 2007). Disruptive mutations include those that introduce a STOP codon, as well as certain mutants within DNAbinding domains that result in changes in polarity of amino-acid residues. Nondisruptive TP53 mutations include some of the most frequent hotspot mutations, such as R175H, R273H, and $\mathrm{R} 273 \mathrm{C}$, and will often lead to p53 mutant proteins that show GOF properties (MolinaVila et al. 2014). Disruptive and truncating mutations were associated with worse prognosis in patients with surgically resected squamous cell carcinoma of the head and neck (Poeta et al. 2007; Lindenbergh-van der Plas et al. 2011; Skinner et al. 2012). To the contrary, nondisruptive TP53 mutations were associated with shorter survival in patients with advanced non-smallcell lung cancer (Molina-Vila et al. 2014).

Synonymous or silent mutations (those that do not lead to a change in the coded amino acid) have generally been overlooked because they were perceived as being neutral. However, it has long been suspected that silent TP53 mutations may alter splicing patterns (Hongyo et al. 1995; Lamolle et al. 2006). A large genomic study of matched cancer exomes and RNA sequencing has recently confirmed that TP53 is unique among tumor-suppressor genes in that recurrent synonymous mutations inactivate splice sites (Supek et al. 2014). This finding could be clinically relevant, as instances of silent TP53 mutations associated with poor survival have been reported in the literature (Sturm et al. 2003). Moreover, the patterns of p53 protein isoform expression, as further detailed below, may also be altered by mutations that affect splicing.

\section{TP53 ISOFORM EXPRESSION AND CANCER OUTCOME}

The vast majority of studies describing abnormal p53 function in cancers have so far focused on its main full-length isoform (i.e., p53FL, p53 $\alpha$, TAp53 $\alpha$ ). However, TP53 encodes at least 13 different isoforms through alternative promoter usage, alternative splicing, and alternative translation start sites (Bourdon 2007; Marcel et al. 2010; Senturk et al. 2014). Evidence indicating that patterns of isoform expression can have prognostic value is starting to surface. So far, these studies have focused on quantifying p53 isoforms at the mRNA level. Expression of p53 $\gamma$, but not p53 $\beta$, in breast cancer patients bearing TP53 mutant tumors resulted in overall survival that was similar to that of patients with TP53 WT tumors (Bourdon et al. 2011), whereas a recent study showed that expression of the $\mathrm{p} 53 \beta$ but not the $\mathrm{p} 53 \gamma$ isoform was protective in patients bearing TP53 mutant tumors (AveryKiejda et al. 2014). Expression of the $\Delta 40 \mathrm{p} 53$ isoform has been associated with triple-negative breast cancer, an aggressive breast cancer subtype (Avery-Kiejda et al. 2014), and mucinous ovarian cancer, but it conferred a favorable prognosis in the latter (Hofstetter et al. 2012). Studies that combine transcriptomic and sequencing analysis will enable the generation of hypothesis regarding the interplay between $\mathrm{p} 53$ isoforms and TP53 mutations. Silent mutations may affect the ratio at which protein isoforms are expressed, and truncated variants may affect the function of mutant p53FL. An additional level of complexity is found at the protein level. $\Delta 133$ p53 protein isoforms are regulated by selective autophagy (Horikawa et al. 2014); thus, evaluating mRNA alone is insufficient to fully 
characterize the expression of p53 isoforms and their prognostic value.

\section{EMERGING AREAS FOR CLINICAL APPLICATIONS OF TP53 MUTATION TESTING}

\section{Cancer Stem Cells}

Recent reports have revealed that p53 regulates stem-cell homeostasis and pluripotency. WT p53 negatively regulates proliferation and selfrenewal of neural (Meletis et al. 2006) and hematopoietic (Liu et al. 2009) stem cells. In mice, loss of p53 leads to expansion of the mammary stem-cell pool, through increased frequency of symmetric cell divisions (Cicalese et al. 2009). Moreover, p53 suppresses somatic cell reprogramming and its inactivation results in enhanced efficiency of induced pluripotent stem (iPS) formation (Hong et al. 2009; Kawamura et al. 2009; Marion et al. 2009). Mutant p53 can further enhance somatic cell reprogramming; however, iPS cells generated in the presence of mutant $\mathrm{p} 53$ give rise to malignant tumors (Sarig et al. 2010). Surprisingly, mutant p53 did not affect the quality of reprogramming of fibroblasts from LFS patients (Lee et al. 2015). However, the R175H GOF mutant promoted the expansion of mammary stem cells and cancer initiation (Lu et al. 2013). Thus, mutant p53 appears capable of tipping the balance between pluripotency and tumor formation (Rivlin et al. 2015). Consistently, the presence of TP53 mutations correlates with stem-cell-like geneexpression patterns in diverse types of cancer (Mizuno et al. 2010; Villanueva and Hoshida 2011; Woo et al. 2011; Schwede et al. 2013). The hypothesis that mutant p53 or a compromised p53 network can promote the development of dedifferentiated cells with self-renewal properties (also known as "cancer stem cells") has clinical implications. Cancer stem cells are conceptually at the top of the hierarchy within a tumor and bear the capacity for sustaining tumor growth, and regenerating tumor heterogeneity. Cancer stem cells can be resistant to therapies that reduce tumor bulk, and are, therefore, responsible for micrometastatic disease and local recurrence. Their existence challenges the current paradigm of cancer treatment by implying that the fundamental test of most therapies, that is, their ability to reduce tumor size, may be inadequate unless it is ensured that the subpopulation of cells within a tumor with selfrenewal properties is completely eradicated. Knowing that tumors bearing mutated p53 may be rich in cancer stem cells may inform treatment modalities so that they are aimed at eradicating such subpopulations of cells.

\section{Liquid Biopsies}

Another emerging area of opportunity for clinical application is the evaluation of TP53 mutations in tumor components shed into the bloodstream (also known as "liquid biopsies"). Examples of this application include targeted deep sequencing of TP53 for longitudinal analysis of circulating tumor DNA (ctDNA), cellfree DNA (cfDNA), or circulating tumor cells (CTCs) to monitor cancer recurrence (Forshew et al. 2012; Dawson et al. 2013; Fernandez et al. 2014; Rothe et al. 2014; Hamakawa et al. 2015). Recently, Bettegowda et al. (2014) showed that digital PCR can detect tumor-related mutations in the plasma of patients with multiple different types of cancer suggesting that ctDNA is potentially a sensitive and specific biomarker that can be used for a variety of clinical and research purposes, including the determination of clinically relevant mutations. This comprehensive study that included $>600$ patient samples also established two important caveats for this analysis: that abundance of ctDNA is determined by tumor type (i.e., some tumors "shed" more DNA into the bloodstream) and tumor burden (i.e., size and stage), and that ctDNA can be found in samples without detectable CTCs.

\section{Intratumor Evolution and Heterogeneity}

Systematic characterization of intratumor heterogeneity through deep sequencing of multiple regions of a tumor has revealed a dynamic process of clonal evolution that affects therapeutic response, metastatic spread, and, ultimately, patient outcome (Burrell et al. 2013). Although 
A.I. Robles et al.

intratumor heterogeneity of TP53 mutations and p53 staining has long been appreciated, these studies have shed new light on the role of p53 alterations for shaping a tumor's subclonal architecture. The association of TP53 mutations with clonal diversity is of particular interest in chronic lymphocytic leukemia (CLL), as p53 alterations have unambiguously been linked with adverse outcome of this disease (Malcikova et al. 2014). Sequencing of samples collected longitudinally through cycles of chemotherapy revealed that chemotherapy resulted in the expansion of clones with driver mutations (including TP53 mutations) and this expansion can hasten disease progression (Landau et al. 2013; Rossi et al. 2014; Malcikova et al. 2015). This finding has important implications for clinical management of CLL patients, as the sensitivity afforded by NGS allows detection of small subclones bearing TP53 mutations in pretreatment samples, possibly identifying patients at high risk for clonal expansion and acquisition of therapeutic resistance.

\section{TP53 AT THE CROSSROADS OF CLINICAL GENOMICS AND CANCER THERAPY}

The advent of comprehensive genomic characterization through NGS has brought to the forefront the often complex and idiosyncratic genetic changes associated with cancer development. In the clinical setting, these alterations provide new opportunities to help physicians select more appropriate drugs or ongoing clinical trials for a given patient. This approach is aligned with the oncology "precision medicine" initiative recently put forward by the National Institutes of Health (Collins and Varmus 2015). Precision oncology trials, most notably the just-launched NCI-MATCH (cancer.gov/nci-match) trial (McNeil 2015), aim to evaluate the extent to which genomics-based treatments will be able to improve patient performance. However, the large set of data associated with NGS-based reports is generally very lengthy, inconclusive, and not readily understandable by clinicians not intimately familiar with the technology and the rapidly evolving field. In response to these challenges, Genomic Tumor Boards that bring to- gether an interdisciplinary group of experts, including internists, oncologists, surgeons, biostatisticians, radiologists, pathologists, clinical geneticists, basic and translational science researchers, and bioinformaticians, convene to discuss the intricacies of tumor genetics and tailor a personalized treatment plan for patients who often have advanced cancer or have exhausted standard therapies. Being one of the most commonly altered genes in cancer, TP53 mutations are frequently observed in advanced tumors. Their presence is discussed in the context of other molecular changes for determining a potentially more effective treatment strategy. Not infrequently, a recommendation can be made when there is an appropriate and effective drug for a given genomic alteration, such as EGFR gene mutations or $A L K$ fusions in lung cancer, or BRAF V600E in melanoma (Kelleher et al. 2012). However, obstacles abound because of the experimental nature of the clinical trials, the lack of a clear targetable drug for the vast majority of mutations found through large-scale sequencing, and the absence of strong evidence that a particular treatment might actually be effective for an individual patient. TP53 mutations, in particular, are not currently "clinically actionable" (Meric-Bernstam et al. 2015); thus, making use of the molecular genetic information, including the tumor status of TP53, to effectively improve patient care remains a challenge in clinical settings. In the not-too-distant future, however, the presence of TP53 mutations may indeed inform targeted therapeutic approaches. Therapeutic strategies aimed at restoring p53 pathway function are showing promising results in clinical trials (refer to the literature for further details). These include approaches to disrupt the interaction of p53 with MDM2 (Khoo et al. 2014), replace its key downstream microRNA target miR-34 (Bader 2012), or directly restore function to mutant p53 (Lehmann et al. 2012).

Analogous to sensitivity tests for antibiotics routinely used in clinical practice for management of infections and for tumors without a targetable driver mutation, it would be ideal if the individual tumor being profiled for genomic alterations could also be rapidly expanded 
ex vivo to enable functional screenings against a panel of all available antitumor drugs before being recommended for the patient. These patient-derived tumor xenografts (PDTXs) are currently a valuable resource for study (Tentler et al. 2012) and increasingly performing as predictors of response to targeted therapy (Stewart et al. 2015). Because TP53 is ubiquitously altered in cancers, TP53 mutations are a tool to confirm the provenance of PDTX (Park et al. 2013; Walters et al. 2013; Dodbiba et al. 2015). Moreover, selection pressures that lead to expansion of aggressive clones on implantation of primary tumors appear to replicate metastat- ic colonization such that TP53 mutations found in PTDX can serve as a beacon to track the origin of metastases back to minor subclones present in the primary tumors (Bousquet et al. 2015). Additional resources and further development are needed before PTDX can become an integral part of a cancer patient's clinical care as a platform to help define therapies based on the molecular make-up of an individual tumor.

\section{CONCLUDING REMARKS}

The precision medicine strategy includes four basic premises (Fig. 4) (National Research

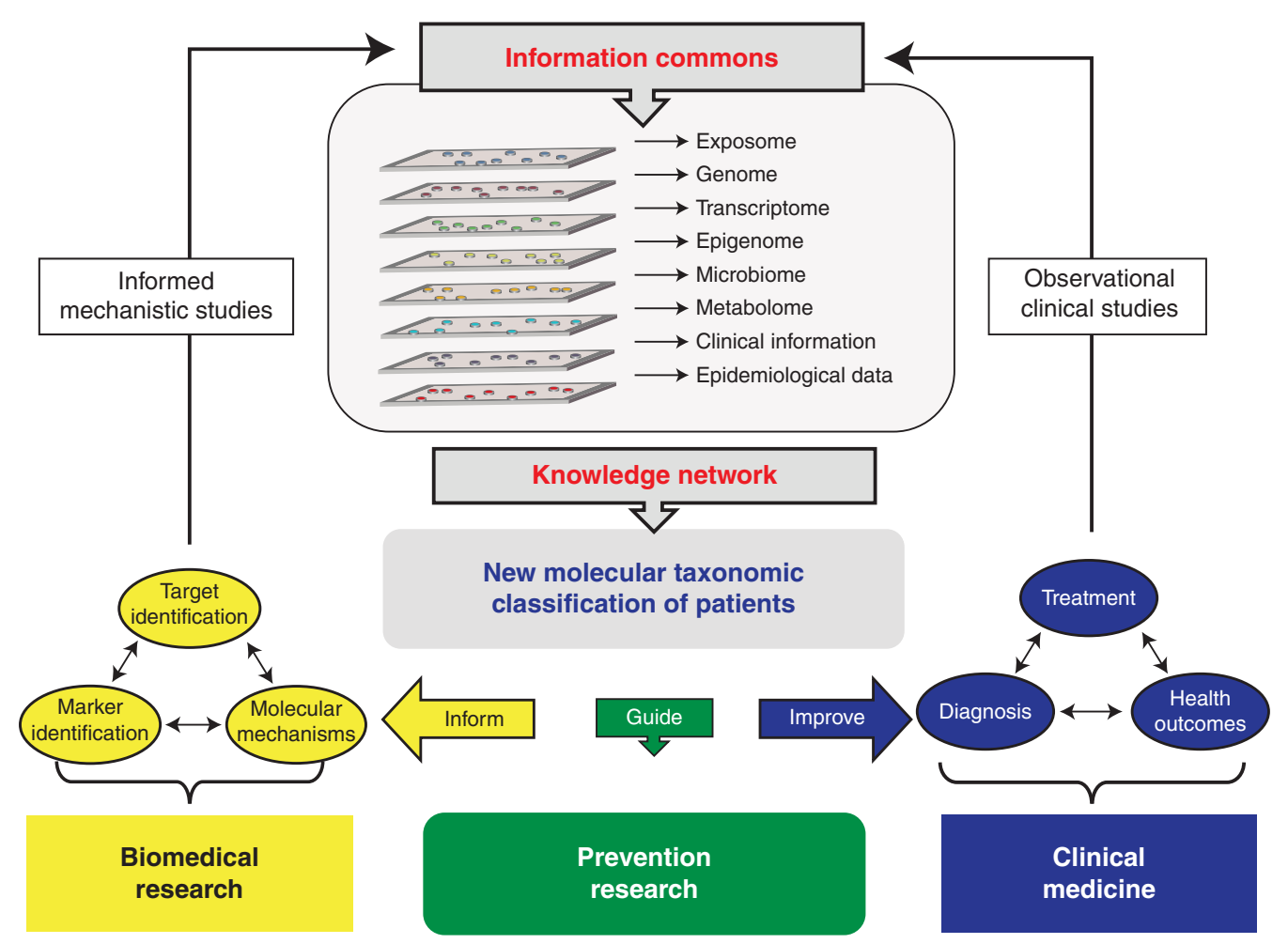

Figure 4. A Precision Medicine research strategy. As outlined in the 2011 Institute of Medicine's National Research Council report "Toward Precision Medicine: Building a Knowledge Network for Biomedical Research and a New Taxonomy of Disease" (National Research Council 2011), Precision Medicine starts with the creation of an Information Commons that interactively houses multiple "-omics" data types (genomics, epigenomics, transcriptomics, metabolomics, proteomics) along with historical exposure and lifestyle information from individual patients. Bioinformatic integration of these data will lead to the development of a Knowledge Network that will be used to improve disease taxonomy, the application of clinical medicine and the study of molecular mechanisms of disease. An iterative process of acquiring information in individuals or cohorts of patients, making improvements in taxonomy and using that knowledge to care for patients and design new studies that further feed the Information Commons will refine the molecular taxonomic classifiers and improve clinical medicine. 
A.I. Robles et al.

Council 2011). First, the "Information Commons" for each cancer type has to be populated with a variety of "-omic" (exposome, genome, epigenome, transcriptome, metabolome, microbiome) analyses, as well as clinical information and epidemiological data from individual patients. Second, these data are integrated into a "Knowledge Network" that examines the interconnectivity of each layer of data from the Information Commons. Third, this knowledge network is used to develop new "Taxonomic Classifiers" with the goal of improving patient diagnosis, decisions on therapeutic strategies, and cancer-related health outcomes. Finally, this knowledge is used to guide biomedical, prevention, and clinical research to perform relevant mechanistic and observational studies. These data are used to validate previous observations in new cohorts to ensure the integrity of the Knowledge Network and to make decisions about what new data should be added to the information commons to further improve and refine the molecular taxonomic classifiers representing the intrinsic biological distinctions. p53 and its functions contribute to the "Hallmarks of Cancer" (Hanahan and Weinberg 2011), as discussed in other articles in this collection, and can be analyzed within the frame- work of "omics" Precision Medicine to improve disease taxonomy and medical care of individual patients, and guide disease prevention and biomedical research. As shown in Figure 5, TP53 mutations can potentially affect, and be modulated by, multiple OMICS in the Precision Medicine paradigm. Within the "exposome," TP53 somatic mutations can be linked to dietary and environmental exposures (e.g., aflatoxin B1, cigarette smoke, etc., as described earlier). TP53 mutations with less-understood etiology comprise most of the common somatic mutations found in the "genome" of human cancers. Some of these have characteristic GOF phenotypes and can predict poor patient prognosis (Brosh and Rotter 2009). In addition, TP53 bears common germline polymorphisms that affect certain biochemical properties of the protein (Whibley et al. 2009). As a transcription factor activated by cellular stress, p53 regulates the expression of an ever-growing list of protein-coding and noncoding mRNAs in the "transcriptome," mainly involved in cell-cycle checkpoint, DNA repair, senescence, and apoptosis (Li et al. 2012). Mutant p53 can also manifest GOF phenotypes through unique transcriptional effects (Oren and Rotter 2010). p53 also modulates the "epigenome," via up-regulation of the miR-34 fam-

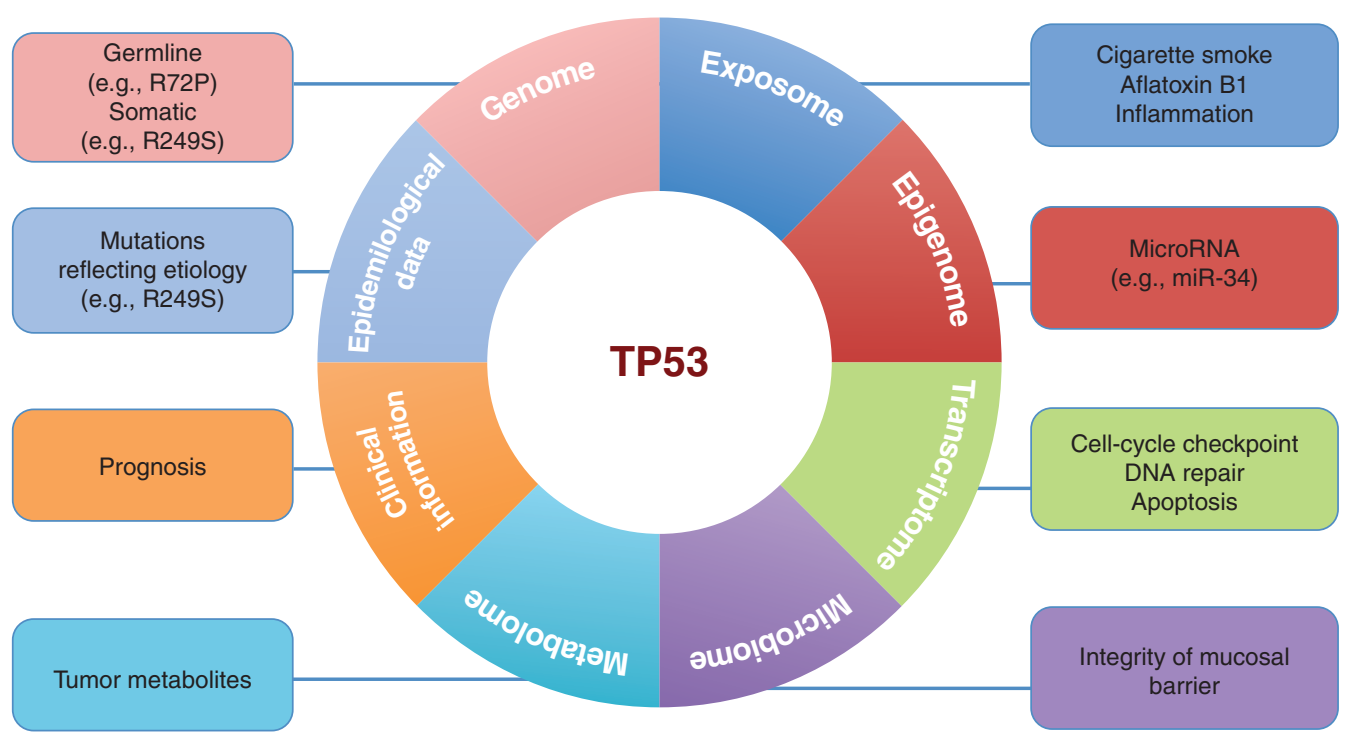

Figure 5. p53 and its functions affect multiple layers of "-omics" data in the Precision Medicine paradigm. 
ily of microRNAs (Bommer et al. 2007; Chang et al. 2007; Corney et al. 2007; He et al. 2007; Hermeking 2007; Raver-Shapira et al. 2007; Tarasov et al. 2007; Tazawa et al. 2007). The role of p53 in tumor metabolism is central to the "metabolome" (Berkers et al. 2013) (see also the review by Humpton and Vousden 2016). Mutant p53 promotes metabolic changes that support tumor growth including enhanced tumor lipid metabolism (Freed-Pastor et al. 2012) and glucose uptake (Zhang et al. 2013). Emerging evidence indicates that compromised p53 function also affects the tumor "microbiome" by reducing the mucosal barrier that prevents bacterial infiltration (Schwitalla et al. 2013). Conceivably, the presence of mutant p53 could modulate the extent, and even the type of microbial changes observed in tumors. With this in mind, it should be clinically useful to consider TP53 mutations in the context of each of the other layers of information available for an individual patient, whether or not acquired as part of a comprehensive screen.

\section{ACKNOWLEDGMENTS}

We thank Mr. Mohammed Khan for graphic design support. J.J. is supported in part by the Mayo Clinic Center for Individualized Medicine, Biomarker Discovery Program.

\section{REFERENCES}

${ }^{*}$ Reference is also in this collection.

Alexandrov LB, Nik-Zainal S, Wedge DC, Aparicio SA, Behjati S, Biankin AV, Bignell GR, Bolli N, Borg A, BorresenDale AL, et al. 2013. Signatures of mutational processes in human cancer. Nature 500: 415-421.

Avery-Kiejda KA, Morten B, Wong-Brown MW, Mathe A, Scott RJ. 2014. The relative mRNA expression of p53 isoforms in breast cancer is associated with clinical features and outcome. Carcinogenesis 35: 586-596.

Bader AG. 2012. miR-34-A microRNA replacement therapy is headed to the clinic. Front Genet 3: 120

Berkers CR, Maddocks OD, Cheung EC, Mor I, Vousden KH. 2013. Metabolic regulation by p53 family members. Cell Metab 18: 617-633.

Bettegowda C, Sausen M, Leary RJ, Kinde I, Wang Y, Agrawal N, Bartlett BR, Wang H, Luber B, Alani RM, et al. 2014. Detection of circulating tumor DNA in earlyand late-stage human malignancies. Sci Transl Med 6: 224 ra24.
Bisio A, Ciribilli Y, Fronza G, Inga A, Monti P. 2014. TP53 mutants in the tower of babel of cancer progression. Hum Mutat 35: 689-701.

Bommer GT, Gerin I, Feng Y, Kaczorowski AJ, Kuick R, Love RE, Zhai Y, Giordano TJ, Qin ZS, Moore BB, et al. 2007. p53-mediated activation of miRNA34 candidate tumorsuppressor genes. Curr Biol 17: 1298-1307.

Bourdon JC. 2007. p53 and its isoforms in cancer. $\mathrm{Br} \mathrm{J}$ Cancer 97: 277-282.

Bourdon JC, Khoury MP, Diot A, Baker L, Fernandes K, Aoubala M, Quinlan P, Purdie CA, Jordan LB, Prats AC, et al. 2011. p53 mutant breast cancer patients expressing p53 $\gamma$ have as good a prognosis as wild-type p53 breast cancer patients. Breast Cancer Res 13: R7.

Bousquet G, Bouchtaoui ME, Leboeuf C, Battistella M, Varna M, Ferreira I, Plassa LF, Hamdan D, Bertheau P, Feugeas JP, et al. 2015. Tracking sub-clonal TP53 mutated tumor cells in human metastatic renal cell carcinoma. Oncotarget 5: 19279-19289.

Brachova P, Thiel KW, Leslie KK. 2013. The consequence of oncomorphic TP53 mutations in ovarian cancer. Int J Mol Sci 14: 19257-19275.

Brachova P, Mueting SR, Carlson MJ, Goodheart MJ, Button AM, Mott SL, Dai D, Thiel KW, Devor EJ, Leslie KK. 2015. TP53 oncomorphic mutations predict resistance to platinum and taxane-based standard chemotherapy in patients diagnosed with advanced serous ovarian carcinoma. Int J Oncol 46: 607-618.

Brash DE, Rudolph JA, Simon JA, Lin A, McKenna GJ, Baden HP, Halperin AJ, Ponten J. 1991. A role for sunlight in skin cancer: UV-induced p53 mutations in squamous cell carcinoma. Proc Natl Acad Sci 88: 10124-10128.

Bressac B, Kew M, Wands J, Ozturk M. 1991. Selective G to T mutations of p53 gene in hepatocellular carcinoma from southern Africa. Nature 350: 429-431.

Brosh R, Rotter V. 2009. When mutants gain new powers: News from the mutant p53 field. Nat Rev Cancer 9: $701-$ 713.

Burrell RA, McGranahan N, Bartek J, Swanton C. 2013. The causes and consequences of genetic heterogeneity in cancer evolution. Nature 501: 338-345.

Cerami E, Gao J, Dogrusoz U, Gross BE, Sumer SO, Aksoy BA, Jacobsen A, Byrne CJ, Heuer ML, Larsson E, et al. 2012. The cBio cancer genomics portal: An open platform for exploring multidimensional cancer genomics data. Cancer Discov 2: 401-404.

Chak BP, Chan ES, Tong JH, Leung AW, Cheng FW, Lam GK, Shing MM, Li CK, To KF. 2015. Germline TP53 mutations is common in patients with two early-onset primary malignancies. Clin Genet 87: 499-501.

Chang TC, Wentzel EA, Kent OA, Ramachandran K, Mullendore M, Lee KH, Feldmann G, Yamakuchi M, Ferlito M, Lowenstein CJ, et al. 2007. Transactivation of miR-34a by 53 broadly influences gene expression and promotes apoptosis. Mol Cell 26: 745-752.

Chang VY, Federman N, Martinez-Agosto J, Tatishchev SF, Nelson SF. 2013. Whole exome sequencing of pediatric gastric adenocarcinoma reveals an atypical presentation of Li-Fraumeni syndrome. Pediatr Blood Cancer 60: $570-574$. 
A.I. Robles et al.

Chen CH, Dickman KG, Moriya M, Zavadil J, Sidorenko VS, Edwards KL, Gnatenko DV, Wu L, Turesky RJ, Wu XR, et al. 2012. Aristolochic acid-associated urothelial cancer in Taiwan. Proc Natl Acad Sci 109: 8241-8246.

Churi CR, Shroff R, Wang Y, Rashid A, Kang HC, Weatherly J, Zuo M, Zinner R, Hong D, Meric-Bernstam F, et al. 2014. Mutation profiling in cholangiocarcinoma: Prognostic and therapeutic implications. PLOS ONE 9: e115383.

Cicalese A, Bonizzi G, Pasi CE, Faretta M, Ronzoni S, Giulini B, Brisken C, Minucci S, Di Fiore PP, Pelicci PG. 2009. The tumor suppressor p53 regulates polarity of self-renewing divisions in mammary stem cells. Cell 138: $1083-$ 1095.

Cleary SP, Jeck WR, Zhao X, Chen K, Selitsky SR, Savich GL, Tan TX, Wu MC, Getz G, Lawrence MS, et al. 2013. Identification of driver genes in hepatocellular carcinoma by exome sequencing. Hepatology 58: 1693-1702.

Collins FS, Varmus H. 2015. A new initiative on precision medicine. N Engl J Med 372: 793-795.

Corney DC, Flesken-Nikitin A, Godwin AK, Wang W, Nikitin AY. 2007. MicroRNA-34b and MicroRNA-34c are targets of p53 and cooperate in control of cell proliferation and adhesion-independent growth. Cancer Res 67: 8433 8438.

Dawson SJ, Tsui DW, Murtaza M, Biggs H, Rueda OM, Chin SF, Dunning MJ, Gale D, Forshew T, MahlerAraujo B, et al. 2013. Analysis of circulating tumor DNA to monitor metastatic breast cancer. $N$ Engl Med 368: 1199-1209.

Dodbiba L, Teichman J, Fleet A, Thai H, Starmans MH, Navab R, Chen Z, Girgis H, Eng L, Espin-Garcia O, et al. 2015. Appropriateness of using patient-derived xenograft models for pharmacologic evaluation of novel therapies for esophageal/gastro-esophageal junction cancers. PLOS ONE 10: e0121872.

el-Deiry WS, Kern SE, Pietenpol JA, Kinzler KW, Vogelstein B. 1992. Definition of a consensus binding site for $\mathrm{p} 53$. Nat Genet 1: 45-49.

Fernandez SV, Bingham C, Fittipaldi P, Austin L, Palazzo J, Palmer G, Alpaugh K, Cristofanilli M. 2014. TP53 mutations detected in circulating tumor cells present in the blood of metastatic triple negative breast cancer patients. Breast Cancer Res 16: 445.

Forbes SA, Beare D, Gunasekaran P, Leung K, Bindal N, Boutselakis H, Ding M, Bamford S, Cole C, Ward S, et al. 2015. COSMIC: Exploring the world's knowledge of somatic mutations in human cancer. Nucleic Acids Res 43: D805-811.

Forshew T, Murtaza M, Parkinson C, Gale D, Tsui DW, Kaper F, Dawson SJ, Piskorz AM, Jimenez-Linan M, Bentley D, et al. 2012. Noninvasive identification and monitoring of cancer mutations by targeted deep sequencing of plasma DNA. Sci Transl Med 4: 136ral68.

Frampton GM, Fichtenholtz A, Otto GA, Wang K, Downing SR, He J, Schnall-Levin M, White J, Sanford EM, An P, et al. 2013. Development and validation of a clinical cancer genomic profiling test based on massively parallel DNA sequencing. Nat Biotechnol 31: 1023-1031.

Freed-Pastor WA, Mizuno H, Zhao X, Langerod A, Moon SH, Rodriguez-Barrueco R, Barsotti A, Chicas A, Li W,
Polotskaia A, et al. 2012. Mutant p53 disrupts mammary tissue architecture via the mevalonate pathway. Cell 148: 244-258.

Gonzalez KD, Buzin CH, Noltner KA, Gu D, Li W, Malkin D, Sommer SS. 2009. High frequency of de novo mutations in Li-Fraumeni syndrome. J Med Genet 46: 689-693.

Govindan R, Weber J. 2014. TP53 mutations and lung cancer: Not all mutations are created equal. Clin Cancer Res 20: 4419-4421.

* Guha T, Malkin D. 2016. Inherited TP53 mutations and the Li-Fraumeni syndrome. Cold Spring Harb Perspect Med doi: $10.1101 /$ cshperspect.a026187.

Hamakawa T, Kukita Y, Kurokawa Y, Miyazaki Y, Takahashi T, Yamasaki M, Miyata H, Nakajima K, Taniguchi K, Takiguchi S, et al. 2015. Monitoring gastric cancer progression with circulating tumour DNA. Br J Cancer 112: 352-356.

Hanahan D, Weinberg RA. 2011. Hallmarks of cancer: The next generation. Cell 144: 646-674.

He L, He X, Lim LP, de Stanchina E, Xuan Z, Liang Y, Xue W, Zender L, Magnus J, Ridzon D, et al. 2007. A microRNA component of the p53 tumour suppressor network. $\mathrm{Na}$ ture 447: 1130-1134.

Hermeking H. 2007. p53 enters the microRNA world. Cancer Cell 12: 414-418.

Hofstetter G, Berger A, Berger R, Zoric A, Braicu EI, Reimer D, Fiegl H, Marth C, Zeimet AG, Ulmer H, et al. 2012. The N-terminally truncated p53 isoform $\Delta 40$ p53 influences prognosis in mucinous ovarian cancer. Int J Gynecol Cancer 22: 372-379.

Hollstein M, Sidransky D, Vogelstein B, Harris CC. 1991. p53 mutations in human cancers. Science 253: 49-53.

Holmfeldt L, Wei L, Diaz-Flores E, Walsh M, Zhang J, Ding L, Payne-Turner D, Churchman M, Andersson A, Chen SC, et al. 2013. The genomic landscape of hypodiploid acute lymphoblastic leukemia. Nat Genet 45: $242-252$.

Hong H, Takahashi K, Ichisaka T, Aoi T, Kanagawa O, Nakagawa M, Okita K, Yamanaka S. 2009. Suppression of induced pluripotent stem cell generation by the p53-p21 pathway. Nature 460: 1132-1135.

Hongyo T, Buzard GS, Palli D, Weghorst CM, Amorosi A, Galli M, Caporaso NE, Fraumeni JF Jr, Rice JM. 1995. Mutations of the K-ras and p53 genes in gastric adenocarcinomas from a high-incidence region around Florence, Italy. Cancer Res 55: 2665-2672.

Horikawa I, Fujita K, Jenkins LM, Hiyoshi Y, Mondal AM, Vojtesek B, Lane DP, Appella E, Harris CC. 2014. Autophagic degradation of the inhibitory p53 isoform $\Delta 133 \mathrm{p} 53 \alpha$ as a regulatory mechanism for $\mathrm{p} 53$-mediated senescence. Nat Commun 5: 4706.

Hsu IC, Metcalf RA, Sun T, Welsh JA, Wang NJ, Harris CC. 1991. Mutational hotspot in the p53 gene in human hepatocellular carcinomas. Nature 350: 427-428.

* Humpton TJ, Vousden KH. 2016. Regulation of cellular metabolism and hypoxia by p53. Cold Spring Harb Perspect Med doi: 10.1101/cshperspect.a026146.

Hussain SP, Harris CC. 1999. p53 mutation spectrum and load: The generation of hypotheses linking the exposure 
of endogenous or exogenous carcinogens to human cancer. Mutat Res 428: 23-32.

Hussain SP, Amstad P, Raja K, Ambs S, Nagashima M, Bennett WP, Shields PG, Ham AJ, Swenberg JA, Marrogi AJ, et al. 2000a. Increased p53 mutation load in noncancerous colon tissue from ulcerative colitis: A cancer-prone chronic inflammatory disease. Cancer Res 60: $3333-$ 3337.

Hussain SP, Raja K, Amstad PA, Sawyer M, Trudel LJ, Wogan GN, Hofseth LJ, Shields PG, Billiar TR, Trautwein C, et al. 2000b. Increased p53 mutation load in nontumorous human liver of Wilson disease and hemochromatosis: Oxyradical overload diseases. Proc Natl Acad Sci 97: 12770-12775.

Hussain SP, Amstad P, Raja K, Sawyer M, Hofseth L, Shields PG, Hewer A, Phillips DH, Ryberg D, Haugen A, et al. 2001. Mutability of p53 hotspot codons to benzo(a)pyrene diol epoxide (BPDE) and the frequency of p53 mutations in nontumorous human lung. Cancer Res 61: 6350-6355.

Jelinic P, Mueller JJ, Olvera N, Dao F, Scott SN, Shah R, Gao J, Schultz N, Gonen M, Soslow RA, et al. 2014. Recurrent SMARCA4 mutations in small cell carcinoma of the ovary. Nat Genet 46: 424-426.

Joerger AC, Ang HC, Fersht AR. 2006. Structural basis for understanding oncogenic p53 mutations and designing rescue drugs. Proc Natl Acad Sci 103: 15056-15061.

Kamihara J, Rana HQ, Garber JE. 2014. Germline TP53 mutations and the changing landscape of $\mathrm{Li}-$ Fraumeni syndrome. Hum Mutat 35: 654-662.

Kandoth C, McLellan MD, Vandin F, Ye K, Niu B, Lu C, Xie M, Zhang Q, McMichael JF, Wyczalkowski MA, et al. 2013. Mutational landscape and significance across 12 major cancer types. Nature 502: 333-339.

Kato S, Han SY, Liu W, Otsuka K, Shibata H, Kanamaru R, Ishioka C. 2003. Understanding the function-structure and function-mutation relationships of p53 tumor suppressor protein by high-resolution missense mutation analysis. Proc Natl Acad Sci 100: 8424-8429.

Kawamura T, Suzuki J, Wang YV, Menendez S, Morera LB, Raya A, Wahl GM, Izpisua Belmonte JC. 2009. Linking the p53 tumour suppressor pathway to somatic cell reprogramming. Nature 460: 1140-1144.

Kelleher FC, Solomon B, McArthur GA. 2012. Molecular therapeutic advances in personalized therapy of melanoma and non-small cell lung cancer. J Pers Med 2: $35-49$.

Khoo KH, Verma CS, Lane DP. 2014. Drugging the p53 pathway: Understanding the route to clinical efficacy. Nat Rev Drug Discov 13: 217-236.

Kulasekararaj AG, Smith AE, Mian SA, Mohamedali AM, Krishnamurthy P, Lea NC, Gaken J, Pennaneach C, Ireland R, Czepulkowski B, et al. 2013. TP53 mutations in myelodysplastic syndrome are strongly correlated with aberrations of chromosome 5 , and correlate with adverse prognosis. Br J Haematol 160: 660-672.

Lamolle G, Marin M, Alvarez-Valin F. 2006. Silent mutations in the gene encoding the p53 protein are preferentially located in conserved amino acid positions and splicing enhancers. Mutat Res 600: 102-112.

Landau DA, Carter SL, Stojanov P, McKenna A, Stevenson K, Lawrence MS, Sougnez C, Stewart C, Sivachenko A,
Wang L, et al. 2013. Evolution and impact of subclonal mutations in chronic lymphocytic leukemia. Cell 152: 714-726.

Lawrence MS, Stojanov P, Polak P, Kryukov GV, Cibulskis K, Sivachenko A, Carter SL, Stewart C, Mermel CH, Roberts SA, et al. 2013. Mutational heterogeneity in cancer and the search for new cancer-associated genes. Nature 499: 214-218.

Lee DF, Su J, Kim HS, Chang B, Papatsenko D, Zhao R, Yuan Y, Gingold J, Xia W, Darr H, et al. 2015. Modeling familial cancer with induced pluripotent stem cells. Cell 161: $240-254$.

Lehmann S, Bykov VJ, Ali D, Andren O, Cherif H, Tidefelt U, Uggla B, Yachnin J, Juliusson G, Moshfegh A, et al. 2012. Targeting p53 in vivo: A first-in-human study with p53targeting compound APR-246 in refractory hematologic malignancies and prostate cancer. J Clin Oncol 30: 3633 3639.

Li FP, Fraumeni JF Jr. 1969. Soft-tissue sarcomas, breast cancer, and other neoplasms. A familial syndrome? Ann Intern Med 71: 747-752.

Li FP, Fraumeni JF Jr, Mulvihill JJ, Blattner WA, Dreyfus MG, Tucker MA, Miller RW. 1988. A cancer family syndrome in twenty-four kindreds. Cancer Res 48: 5358-5362.

Li M, He Y, Feng X, Huang J. 2012. Genome-wide studies of the transcriptional regulation by p53. Biochim Biophys Acta 1819: 684-687.

Lindenbergh-van der Plas M, Brakenhoff RH, Kuik DJ, Buijze M, Bloemena E, Snijders PJ, Leemans CR, Braakhuis BJ. 2011. Prognostic significance of truncating TP53 mutations in head and neck squamous cell carcinoma. Clin Cancer Res 17: 3733-3741.

Liu Y, Elf SE, Miyata Y, Sashida G, Liu Y, Huang G, Di Giandomenico S, Lee JM, Deblasio A, Menendez S, et al. 2009. p53 regulates hematopoietic stem cell quiescence. Cell Stem Cell 4: 37-48.

Lu X, Liu DP, Xu Y. 2013. The gain of function of p53 cancer mutant in promoting mammary tumorigenesis. Oncogene 32: 2900-2906.

Lu C, Zhang J, Nagahawatte P, Easton J, Lee S, Liu Z, Ding L, Wyczalkowski MA, Valentine M, Navid F, et al. 2015. The genomic landscape of childhood and adolescent melanoma. J Invest Dermatol 135: 816-823.

Malcikova J, Pavlova S, Kozubik KS, Pospisilova S. 2014. TP53 mutation analysis in clinical practice: Lessons from chronic lymphocytic leukemia. Hum Mutat 35: 663-671.

Malcikova J, Stano-Kozubik K, Tichy B, Kantorova B, Pavlova S, Tom N, Radova L, Smardova J, Pardy F, Doubek M, et al. 2015. Detailed analysis of therapy-driven clonal evolution of TP53 mutations in chronic lymphocytic leukemia. Leukemia 29: 877-885.

Malkin D, Li FP, Strong LC, Fraumeni JF Jr, Nelson CE, Kim DH, Kassel J, Gryka MA, Bischoff FZ, Tainsky MA, et al. 1990. Germ line p53 mutations in a familial syndrome of breast cancer, sarcomas, and other neoplasms. Science 250: $1233-1238$

Marcel V, Perrier S, Aoubala M, Ageorges S, Groves MJ, Diot A, Fernandes K, Tauro S, Bourdon JC. 2010. $\Delta 160$ p53 is a novel N-terminal p53 isoform encoded by $\Delta 133 \mathrm{p} 53$ transcript. FEBS Lett 584: 4463-4468. 
A.I. Robles et al.

Marion RM, Strati K, Li H, Murga M, Blanco R, Ortega S, Fernandez-Capetillo O, Serrano M, Blasco MA. 2009. A p53-mediated DNA damage response limits reprogramming to ensure iPS cell genomic integrity. Nature 460: 1149-1153.

McCuaig JM, Armel SR, Novokmet A, Ginsburg OM, Demsky R, Narod SA, Malkin D. 2012. Routine TP53 testing for breast cancer under age 30: Ready for prime time? Fam Cancer 11: 607-613.

McNeil C. 2015. NCI-MATCH launch highlights new tria design in precision-medicine era. J Natl Cancer Inst 107: djv193.

Meletis K, Wirta V, Hede SM, Nister M, Lundeberg J, Frisen J. 2006. p53 suppresses the self-renewal of adult neural stem cells. Development 133: 363-369.

Meric-Bernstam F, Johnson A, Holla V, Bailey AM, Brusco L, Chen K, Routbort M, Patel KP, Zeng J, Kopetz S, et al. 2015. A decision support framework for genomically informed investigational cancer therapy. J Natl Cancer Inst 107: djv098.

Mirabello L, Yeager M, Mai PL, Gastier-Foster JM, Gorlick R, Khanna C, Patino-Garcia A, Sierrasesumaga L, Lecanda F, Andrulis IL, et al. 2015. Germline TP53 variants and susceptibility to osteosarcoma. J Natl Cancer Inst 107: djv101.

Mizuno H, Spike BT, Wahl GM, Levine AJ. 2010. Inactivation of $\mathrm{p} 53$ in breast cancers correlates with stem cell transcriptional signatures. Proc Natl Acad Sci 107: 22745-22750.

Molina-Vila MA, Bertran-Alamillo J, Gasco A, Mayo-delas-Casas C, Sanchez-Ronco M, Pujantell-Pastor L, Bonanno L, Favaretto AG, Cardona AF, Vergnenegre A, et al. 2014. Nondisruptive p53 mutations are associated with shorter survival in patients with advanced non-small cell lung cancer. Clin Cancer Res 20: 4647-4659.

Moreira AL, Won HH, McMillan R, Huang J, Riely GJ, Ladanyi M, Berger MF. 2015. Massively parallel sequencing identifies recurrent mutations in TP53 in thymic carcinoma associated with poor prognosis. J Thorac Oncol 10: 373-380.

Moriya M, Slade N, Brdar B, Medverec Z, Tomic K, Jelakovic B, Wu L, Truong S, Fernandes A, Grollman AP. 2011. TP53 Mutational signature for aristolochic acid: An environmental carcinogen. Int J Cancer 129: 1532-1536.

National Research Council. 2011. Toward precision medicine: Building a knowledge network for biomedical research and a new taxonomy of disease. National Academies Press, Washington, DC.

Nigro JM, Baker SJ, Preisinger AC, Jessup JM, Hostetter R, Cleary K, Bigner SH, Davidson N, Baylin S, Devilee P, et al. 1989. Mutations in the p53 gene occur in diverse human tumour types. Nature 342: 705-708.

Olivier M, Langerod A, Carrieri P, Bergh J, Klaar S, Eyfjord J, Theillet C, Rodriguez C, Lidereau R, Bieche I, et al. 2006. The clinical value of somatic TP53 gene mutations in 1,794 patients with breast cancer. Clin Cancer Res 12: 1157-1167.

Olivier M, Hollstein M, Hainaut P. 2010. TP53 mutations in human cancers: Origins, consequences, and clinical use. Cold Spring Harb Perspect Biol 2: a001008.

Oren M, Rotter V. 2010. Mutant p53 gain-of-function in cancer. Cold Spring Harb Perspect Biol 2: a001107.
Park B, Jeong BC, Choi YL, Kwon GY, Lim JE, Seo SI, Jeon SS, Lee HM, Choi HY, Lee KS. 2013. Development and characterization of a bladder cancer xenograft model using patient-derived tumor tissue. Cancer Sci 104: $631-638$.

Parkin B, Ouillette P, Yildiz M, Saiya-Cork K, Shedden K, Malek SN. 2015. Integrated genomic profiling, therapy response, and survival in adult acute myelogenous leukemia. Clin Cancer Res 21: 2045-2056.

Parry M, Rose-Zerilli MJ, Ljungstrom V, Gibson J, Wang J, Walewska R, Parker H, Parker AE, Davis Z, Gardiner A, et al. 2015. Genetics and prognostication in splenic marginal zone lymphoma: Revelations from deep sequencing. Clin Cancer Res 21: 4174-4183.

Poeta ML, Manola J, Goldwasser MA, Forastiere A, Benoit N, Califano JA, Ridge JA, Goodwin J, Kenady D, Saunders $\mathrm{J}$, et al. 2007. TP53 mutations and survival in squamouscell carcinoma of the head and neck. $N$ Engl J Med 357: 2552-2561.

Poon SL, Pang ST, McPherson JR, Yu W, Huang KK, Guan P, Weng WH, Siew EY, Liu Y, Heng HL, et al. 2013. Genomewide mutational signatures of aristolochic acid and its application as a screening tool. Sci Transl Med 5: 197ra101.

Raver-Shapira N, Marciano E, Meiri E, Spector Y, Rosenfeld N, Moskovits N, Bentwich Z, Oren M. 2007. Transcriptional activation of miR-34a contributes to $\mathrm{p} 53$-mediated apoptosis. Mol Cell 26: 731-743.

Rivlin N, Koifman G, Rotter V. 2015. p53 orchestrates between normal differentiation and cancer. Semin Cancer Biol 32: 10-17.

Robles AI, Harris CC. 2010. Clinical outcomes and correlates of TP53 mutations and cancer. Cold Spring Harb Perspect Biol 2: a001016.

Rossi D, Khiabanian H, Spina V, Ciardullo C, Bruscaggin A, Fama R, Rasi S, Monti S, Deambrogi C, De Paoli L, et al. 2014. Clinical impact of small TP53 mutated subclones in chronic lymphocytic leukemia. Blood 123: 2139-2147.

Rothe F, Laes JF, Lambrechts D, Smeets D, Vincent D, Maetens M, Fumagalli D, Michiels S, Drisis S, Moerman C, et al. 2014. Plasma circulating tumor DNA as an alternative to metastatic biopsies for mutational analysis in breast cancer. Ann Oncol 25: 1959-1965.

Rucker FG, Schlenk RF, Bullinger L, Kayser S, Teleanu V, Kett H, Habdank M, Kugler CM, Holzmann K, Gaidzik VI, et al. 2012. TP53 alterations in acute myeloid leukemia with complex karyotype correlate with specific copy number alterations, monosomal karyotype, and dismal outcome. Blood 119: 2114-2121.

Sanger F, Nicklen S, Coulson AR. 1977. DNA sequencing with chain-terminating inhibitors. Proc Natl Acad Sci 74: 5463-5467.

Sarig R, Rivlin N, Brosh R, Bornstein C, Kamer I, Ezra O, Molchadsky A, Goldfinger N, Brenner O, Rotter V. 2010. Mutant p53 facilitates somatic cell reprogramming and augments the malignant potential of reprogrammed cells. J Exp Med 207: 2127-2140.

Schetter AJ, Harris CC. 2012. Tumor suppressor p53 (TP53) at the crossroads of the exposome and the cancer genome. Proc Natl Acad Sci 109: 7955-7956.

Schulze K, Imbeaud S, Letouze E, Alexandrov LB, Calderaro J, Rebouissou S, Couchy G, Meiller C, Shinde J, 
Soysouvanh F, et al. 2015. Exome sequencing of hepatocellular carcinomas identifies new mutational signatures and potential therapeutic targets. Nat Genet 47: 505-511.

Schwede M, Spentzos D, Bentink S, Hofmann O, HaibeKains B, Harrington D, Quackenbush J, Culhane AC. 2013. Stem cell-like gene expression in ovarian cancer predicts type II subtype and prognosis. PLoS ONE 8: e57799.

Schwitalla S, Ziegler PK, Horst D, Becker V, Kerle I, BegusNahrmann Y, Lechel A, Rudolph KL, Langer R, SlottaHuspenina J, et al. 2013. Loss of p53 in enterocytes generates an inflammatory microenvironment enabling invasion and lymph node metastasis of carcinogeninduced colorectal tumors. Cancer Cell 23: 93-106.

Senturk S, Yao Z, Camiolo M, Stiles B, Rathod T, Walsh AM, Nemajerova A, Lazzara MJ, Altorki NK, Krainer A, et al. 2014. p53 $\Psi$ is a transcriptionally inactive p53 isoform able to reprogram cells toward a metastatic-like state. Proc Natl Acad Sci 111: E3287-E3296.

Shimizu T, Marusawa H, Matsumoto Y, Inuzuka T, Ikeda A, Fujii Y, Minamiguchi S, Miyamoto S, Kou T, Sakai Y, et al. 2014. Accumulation of somatic mutations in TP53 in gastric epithelium with Helicobacter pylori infection. Gastroenterology 147: 407-417 e403.

Skinner HD, Sandulache VC, Ow TJ, Meyn RE, Yordy JS, Beadle BM, Fitzgerald AL, Giri U, Ang KK, Myers JN. 2012. TP53 disruptive mutations lead to head and neck cancer treatment failure through inhibition of radiationinduced senescence. Clin Cancer Res 18: 290-300.

Srivastava S, Zou ZQ, Pirollo K, Blattner W, Chang EH 1990. Germ-line transmission of a mutated p53 gene in a cancer-prone family with $\mathrm{Li}-$ Fraumeni syndrome. $\mathrm{Na}$ ture 348: 747-749.

Stengel A, Schnittger S, Weissmann S, Kuznia S, Kern W, Kohlmann A, Haferlach T, Haferlach C. 2014. TP53 mutations occur in $15.7 \%$ of ALL and are associated with MYC-rearrangement, low hypodiploidy, and a poor prognosis. Blood 124: 251-258.

Stewart EL, Mascaux C, Pham NA, Sakashita S, Sykes J, Kim L, Yanagawa N, Allo G, Ishizawa K, Wang D, et al. 2015. Clinical utility of patient-derived xenografts to determine biomarkers of prognosis and map resistance pathways in EGFR-mutant lung adenocarcinoma. J Clin Oncol 33: 2472-2480.

Streppel MM, Lata S, DelaBastide M, Montgomery EA, Wang JS, Canto MI, Macgregor-Das AM, Pai S, Morsink FH, Offerhaus GJ, et al. 2014. Next-generation sequencing of endoscopic biopsies identifies ARID1A as a tumorsuppressor gene in Barrett's esophagus. Oncogene 33: 347-357.

Sturm I, Bosanquet AG, Hermann S, Guner D, Dorken B, Daniel PT. 2003. Mutation of p53 and consecutive selective drug resistance in B-CLL occurs as a consequence of prior DNA-damaging chemotherapy. Cell Death Differ 10: $477-484$.

Supek F, Minana B, Valcarcel J, Gabaldon T, Lehner B. 2014. Synonymous mutations frequently act as driver mutations in human cancers. Cell 156: 1324-1335.

Suzuki H, Takahashi T, Kuroishi T, Suyama M, Ariyoshi Y, Takahashi T, Ueda R. 1992. p53 mutations in non-small cell lung cancer in Japan: Association between mutations and smoking. Cancer Res 52: 734-736.
Tarasov V, Jung P, Verdoodt B, Lodygin D, Epanchintsev A, Menssen A, Meister G, Hermeking H. 2007. Differential regulation of microRNAs by p53 revealed by massively parallel sequencing: miR-34a is a p53 target that induces apoptosis and $\mathrm{G}_{1}$-arrest. Cell Cycle 6: 1586-1593.

Tazawa H, Tsuchiya N, Izumiya M, Nakagama H. 2007. Tumor-suppressive miR-34a induces senescence-like growth arrest through modulation of the E2F pathway in human colon cancer cells. Proc Natl Acad Sci 104: 15472-15477.

Tentler JJ, Tan AC, Weekes CD, Jimeno A, Leong S, Pitts TM, Arcaroli JJ, Messersmith WA, Eckhardt SG. 2012. Patientderived tumour xenografts as models for oncology drug development. Nat Rev Clin Oncol 9: 338-350.

Tirode F, Surdez D, Ma X, Parker M, Le Deley MC, Bahrami A, Zhang Z, Lapouble E, Grossetete-Lalami S, Rusch M, et al. 2014. Genomic landscape of Ewing sarcoma defines an aggressive subtype with co-association of STAG2 and TP53 mutations. Cancer Discov 4: $1342-$ 1353.

Tsongalis GJ, Peterson JD, de Abreu FB, Tunkey CD, Gallagher TL, Strausbaugh LD, Wells WA, Amos CI. 2014 Routine use of the Ion Torrent AmpliSeq Cancer Hotspot Panel for identification of clinically actionable somatic mutations. Clin Chem Lab Med 52: 707-714.

Villani A, Tabori U, Schiffman J, Shlien A, Beyene J, Druker H, Novokmet A, Finlay J, Malkin D. 2011. Biochemical and imaging surveillance in germline TP53 mutation carriers with Li-Fraumeni syndrome: A prospective observational study. Lancet Oncol 12: 559-567.

Villanueva A, Hoshida Y. 2011. Depicting the role of TP53 in hepatocellular carcinoma progression. J Hepatol 55: 724725.

Walters DM, Stokes JB, Adair SJ, Stelow EB, Borgman CA, Lowrey BT, Xin W, Blais EM, Lee JK, Papin JA, et al. 2013. Clinical, molecular and genetic validation of a murine orthotopic xenograft model of pancreatic adenocarcinoma using fresh human specimens. PLOS ONE 8: e77065.

Weaver JM, Ross-Innes CS, Shannon N, Lynch AG, Forshew T, Barbera M, Murtaza M, Ong CA, Lao-Sirieix P, Dunning MJ, et al. 2014. Ordering of mutations in preinvasive disease stages of esophageal carcinogenesis. Nat Genet 46: $837-843$.

Weinberg RA. 1991. Tumor suppressor genes. Science 254: $1138-1146$.

Whibley C, Pharoah PD, Hollstein M. 2009. p53 polymorphisms: Cancer implications. Nat Rev Cancer 9: 95-107.

Wild CP. 2005. Complementing the genome with an "exposome": The outstanding challenge of environmental exposure measurement in molecular epidemiology. Cancer Epidemiol Biomarkers Prev 14: 1847-1850.

Woo HG, Wang XW, Budhu A, Kim YH, Kwon SM, Tang ZY, Sun Z, Harris CC, Thorgeirsson SS. 2011. Association of TP53 mutations with stem cell-like gene expression and survival of patients with hepatocellular carcinoma. Gastroenterology 140: 1063-1070.

Yamada H, Shinmura K, Yamamura Y, Kurachi K, Nakamura T, Tsuneyoshi T, Yokota N, Maekawa M, Sugimura H. 2009. Identification and characterization of a novel 
A.I. Robles et al.

germline p53 mutation in a patient with glioblastoma and colon cancer. Int J Cancer 125: 973-976.

Yurgelun MB, Masciari S, Joshi VA, Mercado RC, Lindor NM, Gallinger S, Hopper JL, Jenkins MA, Buchanan DD, Newcomb PA, et al. 2015. Germline TP53 mutations in patients with early-onset colorectal cancer in the Colon Cancer Family Registry. JAMA Oncol 1: $212-214$.
Zenz T, Eichhorst B, Busch R, Denzel T, Habe S, Winkler D, Buhler A, Edelmann J, Bergmann M, Hopfinger G, et al. 2010. TP53 mutation and survival in chronic lymphocytic leukemia. J Clin Oncol 28: 4473-4479.

Zhang C, Liu J, Liang Y, Wu R, Zhao Y, Hong X, Lin M, Yu H, Liu L, Levine AJ, et al. 2013. Tumour-associated mutant p53 drives the Warburg effect. Nat Commun 4: 2935. 


\section{$\&_{\mathrm{CSH}}^{\infty} \&$ Cold Spring Harbor

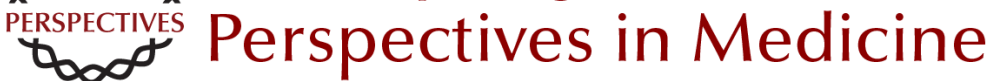

\section{Clinical Outcomes of TP53 Mutations in Cancers}

Ana I. Robles, Jin Jen and Curtis C. Harris

Cold Spring Harb Perspect Med 2016; doi: 10.1101/cshperspect.a026294 originally published online July 22, 2016

\section{Subject Collection The p53 Protein}

Targeting the MDM2-p53 Protein-Protein Interaction for New Cancer Therapy: Progress and Challenges

Shaomeng Wang, Yujun Zhao, Angelo Aguilar, et al.

Structural Evolution and Dynamics of the p53

Proteins

Giovanni Chillemi, Sebastian Kehrloesser,

Francesca Bernassola, et al.

Exploiting the p53 Pathway for Therapy

Chit Fang Cheok and David Philip Lane

The Regulation of Cellular Functions by the p53 Protein: Cellular Senescence

Crystal A. Tonnessen-Murray, Guillermina Lozano and James G. Jackson

The Transactivation Domains of the p53 Protein Nitin Raj and Laura D. Attardi

The Evolution of the Ribosomal Protein-MDM2p53 Pathway

Chad Deisenroth, Derek A. Franklin and Yanping Zhang

Somatic TP53 Mutations in the Era of Genome

Sequencing

Pierre Hainaut and Gerd P. Pfeifer

The Paradox of p53: What, How, and Why? Yael Aylon and Moshe Oren
Control of Cellular Aging, Tissue Function, and Cancer by p53 Downstream of Telomeres Caitlin M. Roake and Steven E. Artandi

Inherited TP53 Mutations and the Li -Fraumeni Syndrome

Tanya Guha and David Malkin

TP53 Mutations in Hypodiploid Acute Lymphoblastic Leukemia

Evan Q. Comeaux and Charles G. Mullighan

Transcriptional Regulation by Wild-Type and

Cancer-Related Mutant Forms of p53

Neil T. Pfister and Carol Prives

The Inherited p53 Mutation in the Brazilian Population

Maria Isabel Achatz and Gerard P. Zambetti

TP53 Mutations in Breast and Ovarian Cancer Laxmi Silwal-Pandit, Anita Langerød and Anne-Lise Børresen-Dale

p53 and the Carcinogenicity of Chronic Inflammation

Andrei V. Gudkov and Elena A. Komarova

Oncogenic Mutant p53 Gain of Function

Nourishes the Vicious Cycle of Tumor

Development and Cancer Stem-Cell Formation

Yoav Shetzer, Alina Molchadsky and Varda Rotter

For additional articles in this collection, see http://perspectivesinmedicine.cshlp.org/cgi/collection/ 